Article

\title{
Antifungal Activity of Eugenol Derivatives against Botrytis Cinerea
}

\author{
Andrés F. Olea ${ }^{1}\left(\mathbb{0}\right.$, Angelica Bravo ${ }^{2}$, Rolando Martínez ${ }^{2}$ (), Mario Thomas ${ }^{2}$, Claudia Sedan ${ }^{2}$, \\ Luis Espinoza ${ }^{3}$ (D), Elisabeth Zambrano ${ }^{4}$, Denisse Carvajal ${ }^{4}$, Evelyn Silva-Moreno ${ }^{4, *}$ \\ and Héctor Carrasco ${ }^{1, *}$ \\ 1 Instituto de Ciencias Químicas Aplicadas, Facultad de Ingeniería, Universidad Autónoma de Chile, \\ San Miguel, Santiago 8900000, Chile; andres.olea@uautonoma.cl \\ 2 Departamento de Ciencias Químicas, Universidad Andrés Bello, Viña del Mar 2520000, Chile; \\ angebravor@gmail.com (A.B.); rmartinez@unab.cl (R.M.); m.thomaselgueda@gmail.com (M.T.); \\ claudiasedan@hotmail.com (C.S.) \\ 3 Departamento de Química, Universidad Técnica Federico Santa María, Valparaíso 2340000, Chile; \\ Luis.espinozac@usm.cl \\ 4 Instituto de Ciencias Biomédicas, Facultad de Ciencias de la Salud, Universidad Autónoma de Chile, \\ San Miguel, Santiago 8900000, Chile; e.zambrano01@ufromail.cl (E.Z.); denisse.carvajals@gmail.com (D.C.) \\ * Correspondence: hector.carrasco@uautonoma.cl (H.C.); evelyn.silva@uautonoma.cl (E.S.-M.); \\ Tel.: +56-223-036-665 (H.C.)
}

Academic Editor: Antonio Evidente

Received: 4 March 2019; Accepted: 26 March 2019; Published: 29 March 2019

\begin{abstract}
Botrytis cinerea is a worldwide spread fungus that causes the grey mold disease, which is considered the most important factor in postharvest losses in fresh fruit crops. Consequently, the control of gray mold is a matter of current and relevant interest for agricultural industries. In this work, a series of phenylpropanoids derived from eugenol were synthesized and characterized. Their effects on the mycelial growth of a virulent and multi-resistant isolate of $B$. cinerea (PN2) have been evaluated and $\mathrm{IC}_{50}$ values for the most active compounds range between 31-95 ppm. The antifungal activity exhibited by these compounds is strongly related to their chemical structure, i.e., increasing activity has been obtained by isomerization of the double bond or introduction of a nitro group on the aromatic ring. Based on the relationship between the fungicide activities and chemical structure, a mechanism of action is proposed. Finally, the activity of these compounds is higher than that reported for the commercial fungicide BC-1000 that is currently employed to combat this disease. Thus, our results suggest that these compounds are potential candidates to be used in the design of new and effective control with inspired natural compounds of this pathogen.
\end{abstract}

Keywords: Botrytis cinerea; eugenol; mycelial growth; resistant isolate; reactive oxygen species; chemical fungicides

\section{Introduction}

B. cinerea is a serious worldwide problem because it causes high losses in pre- and postharvest fresh fruit crops. The high economic losses associated with Botrytis infection represents a growing burden for the agricultural industry [1]. To reduce this effect, a series of control mechanisms have been developed, the application of chemical fungicides being the most spread and more used [2]. Currently, the fungicides available to control B. cinerea on grapevines are hydroxianilides (fenhexamid), anilinopyrimidines (cyprodinil and pyrimethanil), dicarboximide (iprodione), carboxamides (boscalid), strobilurin, phenylpirroles (fludioxonil) and some inhibitors of ergosterol synthesis [3]. However, despite the variety of action mechanisms of these chemical fungicides their indiscriminate use has led 
to the appearance of resistant isolates. This undesirable outcome has prompted the search of new and effective fungicide agents, mainly from natural resources [4-7].

Eugenol (4-allyl-2-methoxyphenol) (1) is a major component of essential oil isolated from the Eugenia caryoplyllata. Much attention has been dedicated to this molecule because it exhibits many different biological activities, such as analgesic [8,9], antimicrobial [10,11], antifungal [12,13], antioxidant [14], anti-inflammatory [15], anti-carcinogenic [16], anti-mutagenic and even repellent properties $[17,18]$.

Various studies of the antifungal activity of eugenol and some analogues (Figure 1) against phytopathogenic and human fungi, have been reported [19-25].

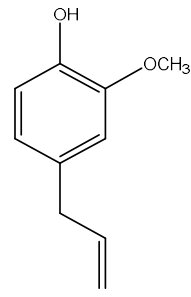

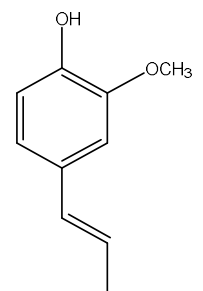

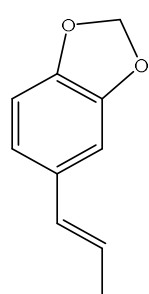

Figure 1. Chemical structure of eugenol (1), isoeugenol (2) and safrole (3).

Zemek et al. [19] reported that $\mathbf{1}$ is almost inactive against Saccharomyces cerevisiae, Candida albicans and Aspergillus niger (MICs around $3000 \mathrm{ppm}$ ), while 2 exhibits a moderate inhibitory effect on the same fungi with MICs ranging between 100 and $250 \mathrm{ppm}$ in both dilution methods. On the other hand, Kubo et al. [20] reported that $\mathbf{1}$ possess moderate activity against $S$. cerevisiae, Candida subtilis, Pityrosporum ovale, and Penicillum chrysogenum, with MICs between 100 to 800 ppm in both dilution methods with shaking, P. ovale being the most sensitive fungus; 1 and 3 exhibit moderate activity against $C$. albicans, i.e., measured MICs were 800 and 200 ppm, respectively [21]; 3 is active against $S$. cerevisiae at 200 ppm [22]. Eugenol has also shown activity against Alternaria sp. and P. chrysogenum, but is inactive against $A$. niger, Botryosphaeria rhodina or Rhizoctonia sp. in agar diffusion assays [23].

Recently, it has been found that $\mathbf{1}$ exhibits effective antifungal activity against Aspergillus, Penicillium, Emericella and Fusarium spp., at concentrations between 100 to $150 \mathrm{ppm}$. This activity has been attributed mainly to the phenolic group [24].

In previous work, we have assessed the antifungal properties of a series of phenylpropanoids including eugenol, safrole and some synthetic derivatives against a panel of opportunistic pathogenic fungi humans. One of these derivatives, 4-allyl-2-methoxy-5-nitrophenol, possesses a high activity on C. albicans and non-albicans Candida spp., Cryptococcus neoformans and dermatophytes. Additionally, it was shown that this molecule did not bind to the main sterol of the fungal membrane up to 250 ppm [25].

However, the antifungal activity of eugenol against $B$. cinerea has been barely studied. The effect of eugenol and its essential oils against four apple pathogens, including B. cinerea, have been evaluated in vitro and in vivo [26]. The MIC value determined for eugenol, incorporated in malt extract agar medium, was $2000 \mathrm{ppm}$, whereas in the saturated atmosphere of volatile eugenol a complete inhibition of mycelial growth of four pathogens was obtained at $150 \mu \mathrm{L}$ of volatile eugenol per liter of air volume. No effect on the germination of all tested pathogens at room temperature was found for eugenol [26].

Recently, the in vitro activity of eugenol on $B$. cinerea has been studied. The $\mathrm{IC}_{50}$ value measured on mycelial radial growth of $B$. cinerea was $38.6 \mathrm{ppm}$; and no bioactivity against conidia germination was observed. Eugenol induces the generation of $\mathrm{H}_{2} \mathrm{O}_{2}$ and increases a free $\mathrm{Ca}^{2+}$ concentration in the cytoplasm. These results strongly support the idea that the antifungal activity of eugenol is due to membrane binding and permeability alteration, leading to destabilization and disruption of the plasma membrane [27]. 
Herein, we report the synthesis of a series of eugenol derivatives (Figure 2), six of them new compounds (8-13), and their evaluation as inhibitors of mycelial growth of a virulent and multidrug-resistant native isolate (PN2). A relationship between the chemical structures of these compounds and their activities is discussed.
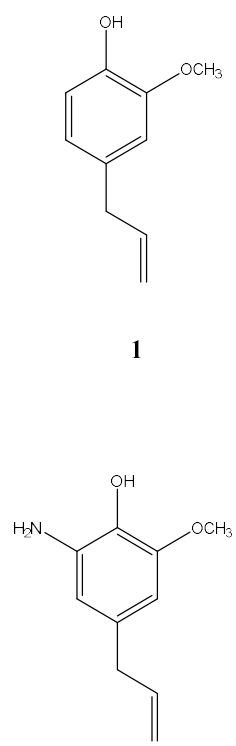

8<smiles>C=CCc1cc(NC(C)=O)c(OC)c(OC)c1</smiles>

13<smiles>C/C=C/c1ccc(Br)c(O)c1</smiles>

4<smiles>C=CCc1cc(N)c(OC(C)=O)c(N(C)C(C)=O)c1</smiles>

9

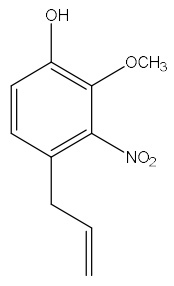

14<smiles>C=C(C)Cc1ccc(/C=C/C)cc1O</smiles>

5<smiles>C=CCc1cc(O)c(OC(C)=O)c(C#N)c1</smiles>

10<smiles>C=CCc1cc(OC)c(O)cc1[N+]#N</smiles>

15<smiles>C/C=C/c1ccc(O)c(O)c1</smiles>

6<smiles>C=CCc1cc(OC)c(OC)c([N+](=O)[O-])c1</smiles>

11<smiles>C=CCc1ccc(CC(C)=O)c(OC)c1[N+](=O)[O-]</smiles>

16<smiles>C=CCc1cc(O)c(Br)c(O)c1</smiles>

7<smiles>C=CCc1cc(N)c(OC)c(OC)c1</smiles>

12<smiles>C=CCc1cc(OC)c(OC(C)=O)cc1[N+](=O)[O-]</smiles>

17

Figure 2. Chemical structures of synthesized eugenol derivatives.

\section{Results}

A series of eugenol derivatives have been synthesized and their antifungal properties have been evaluated (see Figure 2). The synthesis and spectroscopic characterization of compounds 4-7, and $\mathbf{1 4 - 1 7}$ have been previously described $[25,26]$. In this work, new compounds $\mathbf{8 - 1 3}$ have been synthesized and a full spectroscopic characterization is given. Eugenol derivatives 8, 10 and $\mathbf{1 1}$ were obtained from 4-allyl-2-methoxy-6-nitrophenol (7) with high reaction yields (55-80\%). The reduction of aromatic nitro group in $\mathbf{7}$ and $\mathbf{1 1}$ gives anilines $\mathbf{8}$ and $\mathbf{1 2}$ with 70 and $45 \%$ of reaction yield, respectively. Finally, the acetylation of 8 and 12 leads to 9 and 13 with 70\% and 53\% reaction yield, respectively. All these syntheses were carried out following standard procedures.

The antifungal activity of eugenol and its derivatives was studied using PN2, a resistant Botrytis cinerea native isolate. This isolate was obtained from cherry fruit and presents resistance to fenhexamid, iprodione, pyrimethanil and boscalid. The virulence of this isolate was assessed using a tomato and the results are shown in Figure 3. 


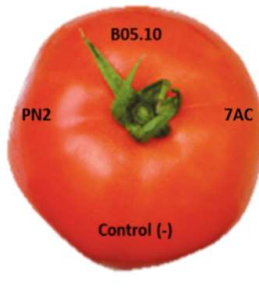

Control

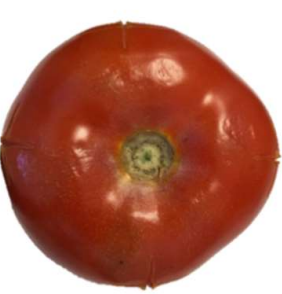

$1 \mathrm{~d} . \mathrm{p} . \mathrm{i}$

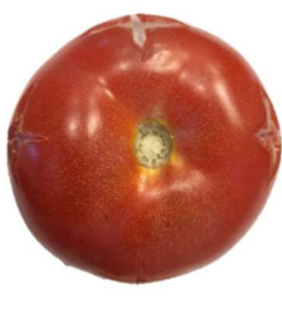

2 d.p.i

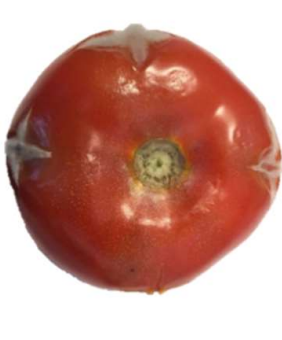

3 d.p.i

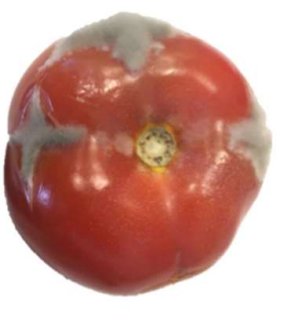

4 d.p.i

Figure 3. Virulence assay of damage produced by Botrytis on tomato after inoculating fruit with $10 \mu \mathrm{L}$ of conidia suspension $\left(2.5 \times 10^{6}\right.$ conidia $\left./ \mathrm{mL}\right)$ and incubated at $22{ }^{\circ} \mathrm{C}$. Gamborg medium was used as negative control, whereas 7AC was used as positive control. Acronyms: B05.10, corresponds to a model isolate; PN2, corresponds to a multi-resistant native isolate; 7AC, corresponds to a native isolate resistant to fenhexamid (gift gently provided by Diagnofruit S.A. Santiago, Chile); dpi means days post inoculation.

Results shown in Figure 3 indicate that an important injury is produced on tomato fruits after four days of inoculation with all tested isolates of $B$. cinerea. The damage is proportional to the post-inoculation time and therefore we may conclude that PN2 is a virulent and resistant native isolate.

\section{Evaluation of Antifungal Activity of Eugenol and Eugenol Derivatives on Botrytis cinerea}

The antifungal activity of eugenol and its derivatives was evaluated in radial growth measurements in malt-yeast medium. The results shown in Figure 4 indicate that the eugenol derivatives affect mycelial growth of $B$. cinerea in a concentration-dependent manner. The percentage of growth inhibition was determined by measuring the mycelial growth in the absence and presence of different concentrations of tested compounds (see Experimental section). Results obtained for the most active compounds are shown in Figure 5.

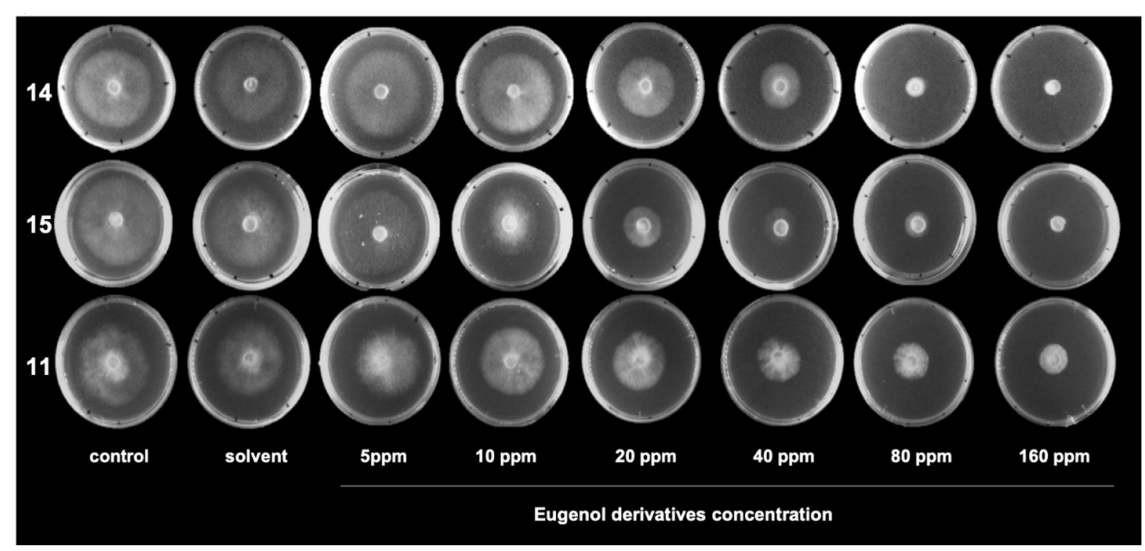

Figure 4. Effect of eugenol derivatives on hyphae growth of Botrytis cinerea in solid media. Photographs of hyphal growth of $B$. cinerea in the absence and presence of different concentrations of 11, 14 and 15 after $48 \mathrm{~h}$ of incubation. 
A

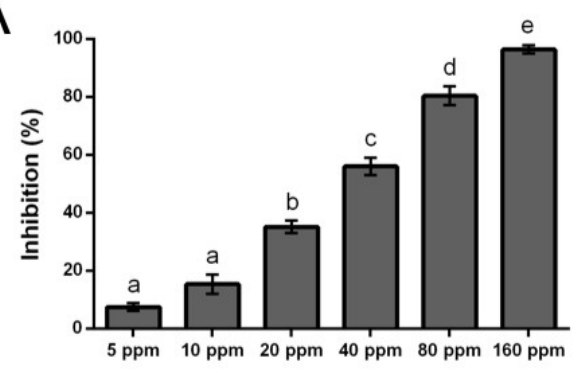

C

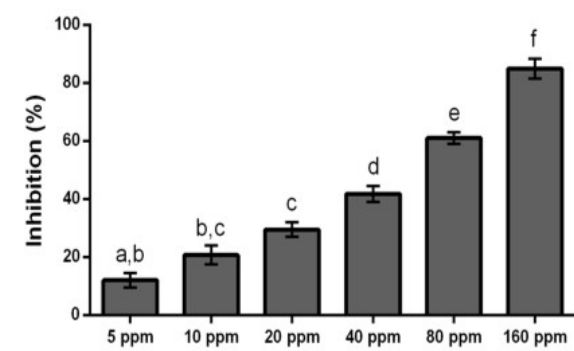

$\mathrm{B}$

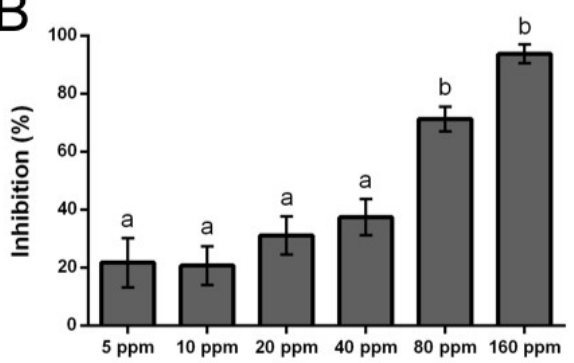

$\mathrm{D}$

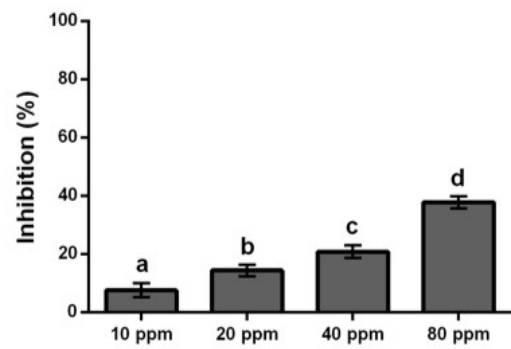

Figure 5. Effect of eugenol derivatives on mycelial growth of Botrytis cinerea in solid media. Percentage of inhibition of mycelial growth determined after $48 \mathrm{~h}$ of incubation at different concentrations: (A) 14, (B) 15, (C) 11, (D) BC-1000 commercial compound used as control. Each bar represents the average of at least three independent experiments \pm standard deviation. (a-f) indicates significant differences between each compound concentration, evaluated by Tukey's test; $p<0.05$.

\section{Discussion}

The antifungal activity was evaluated by the measurement growth inhibition. The fitting of percentage of inhibition to a dose-response curve allows the obtention of $\mathrm{IC}_{50}$ values. The calculated values of $\mathrm{IC}_{50}$ for all assayed compounds are given in Table 1 and range from 31 to $440 \mathrm{ppm}$.

Table 1. $\mathrm{IC}_{50}$ values of eugenol and its synthetic derivatives on in vitro mycelial growth of $B$. cinerea. These values were estimated by measuring the colony diameter after $48 \mathrm{~h}$ of incubation.

\begin{tabular}{cc}
\hline Eugenol Derivatives (from Figure 2) & $\mathbf{I C}_{\mathbf{5 0}}$ ( ppm) \\
\hline $\mathbf{1}$ & 149 \\
$\mathbf{4}$ & 109 \\
$\mathbf{5}$ & 95 \\
$\mathbf{6}$ & 80 \\
$\mathbf{7}$ & 62 \\
$\mathbf{8}$ & $\mathbf{I}^{*}$ \\
$\mathbf{9}$ & 440 \\
$\mathbf{1 0}$ & 221 \\
$\mathbf{1 1}$ & 45 \\
$\mathbf{1 2}$ & $\mathbf{D}^{*}$ \\
$\mathbf{1 3}$ & 103 \\
$\mathbf{1 4}$ & 31 \\
$\mathbf{1 5}$ & 39 \\
$\mathbf{1 6}$ & 108 \\
$\mathbf{1 7}$ & 311 \\
${ }^{*}$ : inactive; ${ }^{*} \mathrm{D}$ : decompose. & 140 \\
\hline
\end{tabular}


The results indicate that the chemical modification of eugenol induces important changes on the antifungal activity of this compound. The antifungal activity of eugenol has been attributed to disruption of the fungal membrane structure, mainly by accumulation of eugenol in the phospholipid bilayer due to its lipophilic character. This interaction alters fluidity and permeability of fungal membranes and affects the function of important membrane-bound enzyme or protein [27].

In this work, the chemical modification of eugenol includes changes in the existing functional groups (Figure 2, compounds 4-6) and the addition of nitrogen-containing group on the aromatic ring (Figure 2, compounds 7-17). In the first group, isomerization of the double bond (compare chemical structures of compounds 1 and 4, Figure 2) has been carried out, and there is almost no effect on eugenol lipophilicity. However, this small structural modification reduces the $\mathrm{IC}_{50}$ value from 149 to $109 \mathrm{ppm}$. In other words, an increase of growth inhibition is induced in eugenol derivatives by conjugation of the side chain double bond with the aromatic system. As lipophilicity is quite similar, the observed increase on the antifungal activity must be explained in terms of an additional mechanism by which molecules 4-6 acts on fungus. A possible explanation is the enhanced Michael-type reaction that could occur between the side propenyl chain and biological nucleophiles. The reaction mechanism would be like that proposed for menadione, a lipid-soluble molecule that causes changes in plasma membrane permeability. Briefly, menadione and compounds 4-6 might react with nucleophilic molecules through a Michael-type reaction generating an intermediate reactive species that later is stabilized by reaction with an acid. A comparison of this mechanism, for menadione and isoeugenol, is depicted in Scheme 1.
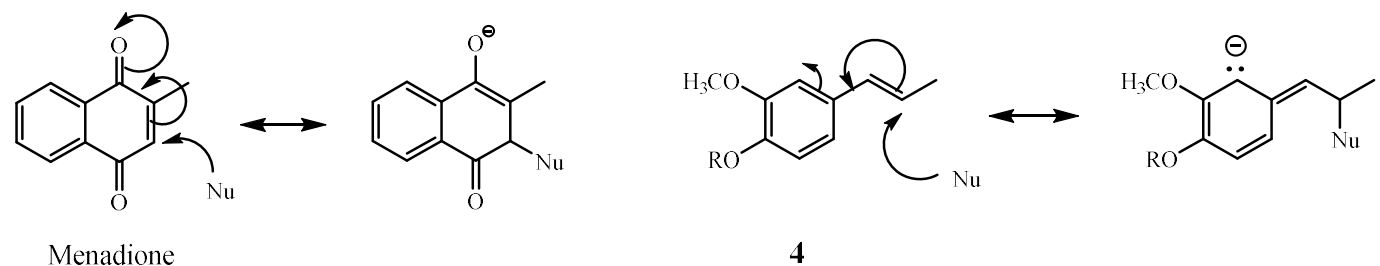

Scheme 1. Reaction mechanism of menadione and isoeugenol with biological nucleophiles.

Further reductions are reached by changing the hydroxyl group to acetyl (5) or methoxy (6) groups, i.e., by decreasing the polarity of isoeugenol.

On the other hand, the addition of nitrogen-containing group on the aromatic ring (Figure 2, compounds 7-17) produces different effects on the antifungal activity. Results shown in Table 1 indicate that introduction of nitro group decreases the $\mathrm{IC}_{50}$ value in a factor of 2.5-4.5 (compounds 7 , 14 and 15 in Table 1). However, this effect disappears when the nitro group is replaced by amine or acetamide groups (compare $\mathrm{IC}_{50}$ values of $\mathbf{7}$ and $\mathbf{8}$, and $\mathbf{1 1}$ and 12, respectively). Considering that the polarity of nitro compounds is higher than that of related eugenol derivatives, the antifungal activity of these compounds, associated to lipophilic concentration in the membrane, should be lower than that shown by eugenol. Therefore, additional mechanisms must be considered to explain the lowest values of $\mathrm{IC}_{50}$ obtained for these compounds. The nitro group is very strong electron withdrawing and might react directly with double bonds substituted with other electron withdrawing groups. In addition, it has been shown that aromatic nitro compounds produce reactive oxygen species (ROS) in an enzymatic-mediated process [28]. Both processes can lead to a chemical disruption of the membrane palisade. The different activities shown by the nitro eugenol derivatives might be attributed to the location of these compounds in the membrane or electronic effect affecting the efficiency of both reactions. Figure 6 depicts a schematic representation of different locations of bioactive compounds into the fungus cell wall.

The compound-position and orientation in the membrane is determined by the chemical structure of the adsorbed molecule. Eugenol and derivatives must orientate themselves with the side alkyl chain parallel to the membrane chains, and the hydroxyl group anchored to the polar surface. Consequently, the nitro group in compound $\mathbf{7}$ is located near the surface, whereas in compound $\mathbf{1 4}$ the nitro group is buried into the palisade. In the latter, the spatial arrangement could enhance the nucleophilic attack of 
double bonds on the electrophilic nitro groups, affecting the membrane permeability and probably the transport of electrons. A similar configuration should be adopted by 15 . This mechanism of action reduces $\mathrm{IC}_{50}$ values from 149 (eugenol) to 62, 31 and 39 ppm for 7, 14 and 15, respectively. The presence of other groups in the aromatic ring may affect the reactivity of nitro compounds either by modifying the electronic distribution or the location in the palisade. For example, the replacement of the hydroxyl group by acetyl decreases strongly the activity of nitroeugenol derivatives, i.e., compares $\mathrm{IC}_{50}$ values of 7 and 10, 14 and 16, 15 and 17. These results can be attributed to the highest electronic attraction of the hydroxyl group, which enhances the nucleophilic reaction with double bonds.

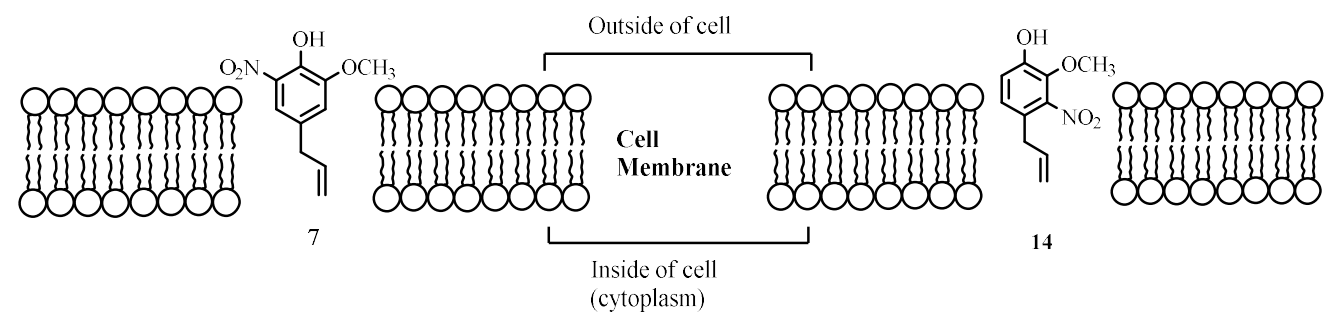

Figure 6. Schematic representation of nitro compounds $\mathbf{7}$ and $\mathbf{1 4}$ location in cell membrane.

The compound-position and orientation in the membrane is determined by the chemical structure of the adsorbed molecule. Eugenol and derivatives must orientate themselves with the side alkyl chain parallel to the membrane chains, and the hydroxyl group anchored to the polar surface. Consequently, the nitro group in compound $\mathbf{7}$ is located near the surface, whereas in compound $\mathbf{1 4}$ the nitro group is buried into the palisade. In the latter, the spatial arrangement could enhance the nucleophilic attack of double bonds on the electrophilic nitro groups, affecting the membrane permeability and probably the transport of electrons. A similar configuration should be adopted by $\mathbf{1 5}$. This mechanism of action reduces $\mathrm{IC}_{50}$ values from 149 (eugenol) to 62, 31 and 39 ppm for 7, 14 and 15, respectively. The presence of other groups in the aromatic ring may affect the reactivity of nitro compounds either by modifying the electronic distribution or the location in the palisade. For example, the replacement of the hydroxyl group by acetyl decreases strongly the activity of nitroeugenol derivatives, i.e. compares $\mathrm{IC}_{50}$ values of 7 and 10, 14 and 16, 15 and 17. These results can be attributed to the highest electronic attraction of the hydroxyl group, which enhances the nucleophilic reaction with double bonds.

On the other hand, the chemical reactivity of the nitro group decreases by substitution of the ortho hydroxy group by a methoxy group (compounds 7 and 11) due to its lower positive inductive effect, but it takes the molecule deeper in the membrane. These two opposite factors induce a slight decrease on the $\mathrm{IC}_{50}$ value.

Thus, our results indicate that the growth inhibition observed for eugenol derivatives evaluated in this work could be a consequence of two different and parallel mechanisms: (i) accumulation in fungal membrane by lipophilic interaction and (ii) Michael-type reactions between eugenol derivatives and membrane components or ROS production by enzymatic reduction of nitro compounds.

The second mechanism seems to be more important and probably these chemical reactions induce the production of reactive oxygen species. It is known that ROS are generated in cells by a variety of processes associated with the normal function of cells or induced by the presence of exogenous cytotoxic substrates. In addition, plants produce high amounts of ROS to avoid fungus infection, and therefore the inability of pathogen to reduce the ROS level may be the cause of fungicide effect [29]. To elucidate this hypothesis, the effect of the most active nitroeugenol derivatives on ROS production has been assessed. Figure 7 shows the luminescence yields measured in the absence and presence of nitro compounds and menadione that is used as a positive control. Luminescence is a measure of $\mathrm{H}_{2} \mathrm{O}_{2}$ concentration or ROS production. 


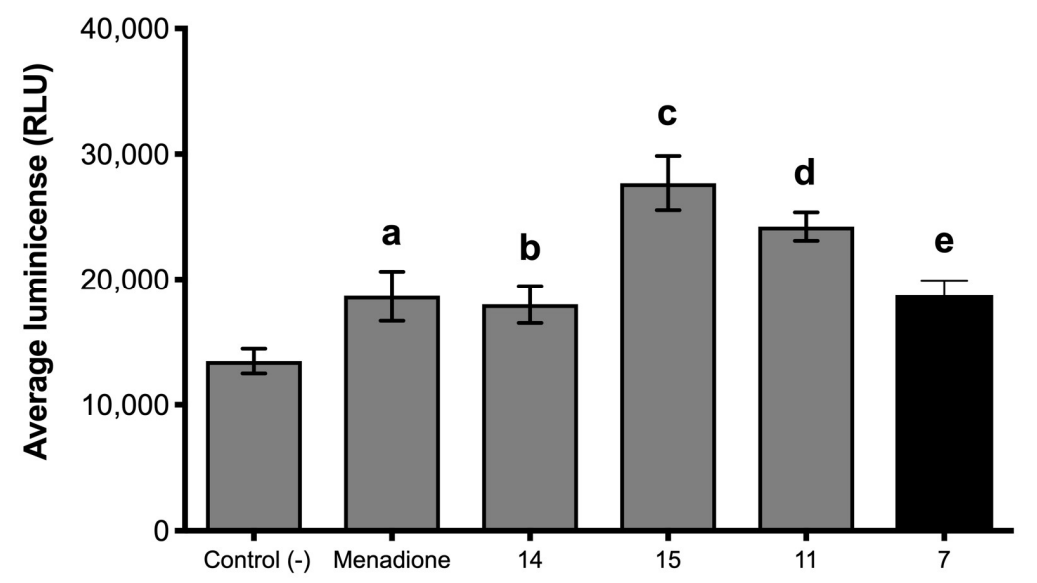

Figure 7. Effect of compounds 7, 11, 14 and 15 on production of reactive oxygen species by Botrytis cinerea. Compounds concentrations were equal to their $\mathrm{IC}_{50}$ values, whereas menadione used as positive control was applied at $10 \mathrm{ppm}$ final concentration $(\mathrm{a}$, and $\mathrm{b}$ indicate statistical differences with respect to the negative control).

The results shown in Figure 7 indicate that nitroeugenol derivatives induce ROS production in conidia in an amount equal or larger than that generated by menadione (positive control), which is a model cytotoxic compound that induces ROS production inside the cell by mitochondria uncoupling [30]. Interestingly, the magnitude of ROS production follows the same order of $\mathrm{IC}_{50}$ values, i.e., $15>11>7$. In other words, the formation of ROS correlates quite well with the inhibition activity suggesting that nitro compounds are acting on the fungus membrane by generating reactive oxygen species and by alteration of membrane in a similar way to that reported for eugenol both in fungi and bacteria [31].

\section{Materials and Methods}

\subsection{Chemistry}

Unless otherwise stated, all chemical reagents were purchased with the highest commercially available purity (Merck, Darmstadt, Germany or Aldrich, St. Louis, MO, USA) and were used without previous purification. Melting points were measured on a Stuart-Scientific SMP3 apparatus and are uncorrected. IR spectra were recorded as thin film or KBr pellets in a Nicolet Impact 420 spectrometer (Thermo Scientific, San Jose, CA, USA). $v_{\max }$ values are expressed in $\mathrm{cm}^{-1} .{ }^{1} \mathrm{H}$ - and ${ }^{13} \mathrm{C}-\mathrm{NMR}$ spectra were recorded in $\mathrm{CDCl}_{3}$ solutions and referenced to the residual peak of $\mathrm{CHCl}_{3}$ at $\delta=7.26 \mathrm{ppm}$ and $\delta=77.00 \mathrm{ppm}$ for ${ }^{1} \mathrm{H}$ and ${ }^{13} \mathrm{C}$, respectively, on a Bruker Avance 400 Digital NMR spectrometer (Bruker, Rheinstetten, Germany), operating at $400.1 \mathrm{MHz}$ for ${ }^{1} \mathrm{H}$ and $100.6 \mathrm{MHz}$ for ${ }^{13} \mathrm{C}$. Chemical shifts are reported in $\delta$ ppm and coupling constants $(J)$ are given in Hz. Silica gel (Merck 200-300 mesh) was used for column chromatography (CC) and silica gel plates and HF-254 for thin layer chromatography (TLC). Spots were detected on TLC by heating after spraying with $25 \% \mathrm{H}_{2} \mathrm{SO}_{4}$ in $\mathrm{H}_{2} \mathrm{O}$. 


\subsection{Synthesis}

Eugenol was isolated from cloves essence, according to the standard procedure [32]. Synthesis of new eugenol derivatives are shown in Scheme 2.

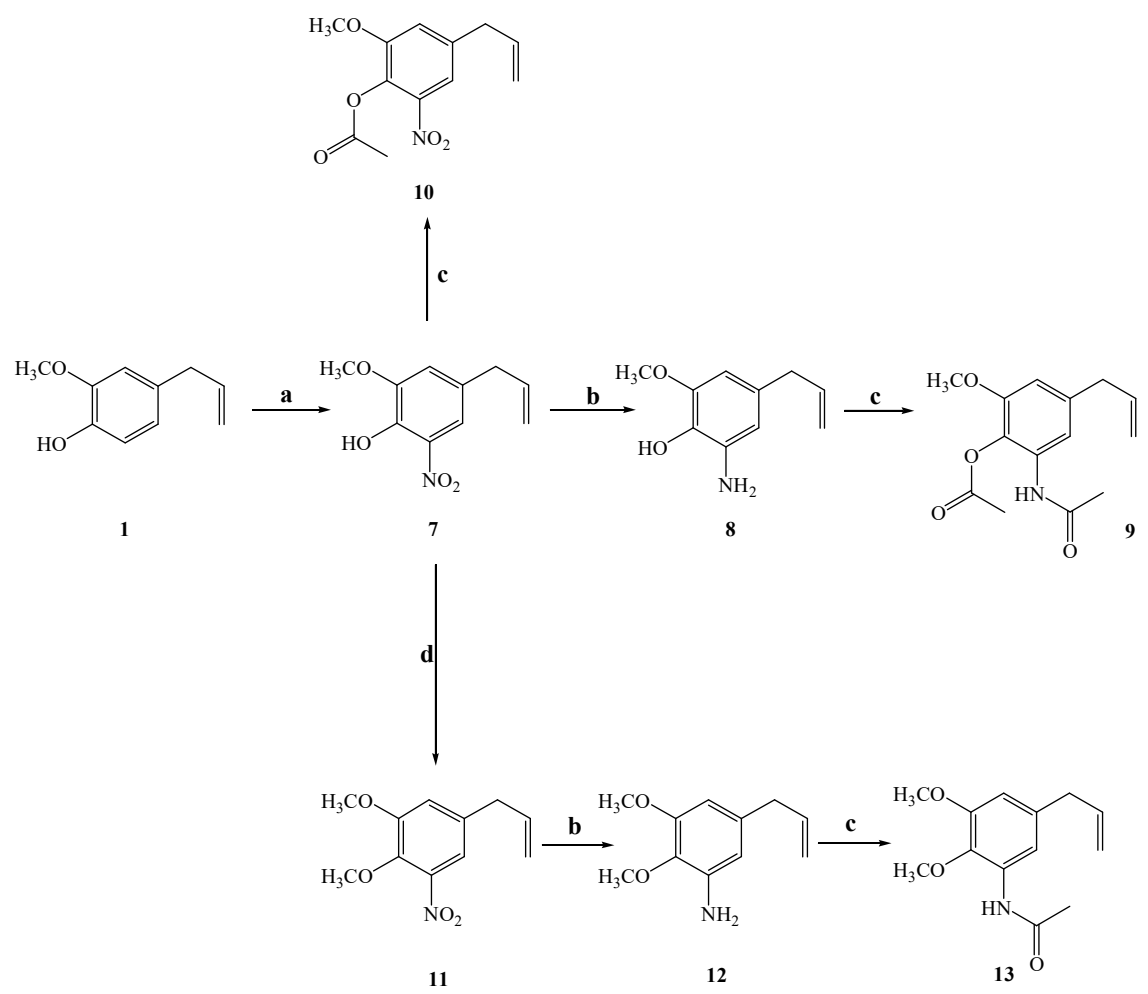

Scheme 2. Synthesis of new eugenol derivatives. Conditions: (a) $\mathrm{NaNO}_{3} / \mathrm{KHSO}_{4}, \mathrm{SiO}_{2} / \mathrm{H}_{2} \mathrm{O}$ (1:1), r.t. 5.5 h; (b) $\mathrm{Zn}, \mathrm{HCOONH}_{4}, \mathrm{MeOH}$, r.t. 5 h; (c) $\mathrm{Ac}_{2} \mathrm{O}, \mathrm{DMAP}, \mathrm{CH}_{2} \mathrm{Cl}_{2}$ r.t 2.5 h; (d) $\left(\mathrm{CH}_{3}\right)_{2} \mathrm{CO}$, dimethylsulphate, $\mathrm{K}_{2} \mathrm{CO}_{3}$, reflux overnight.

\section{General Procedures}

Reduction of nitroeugenol derivatives to anilines. Nitroeugenol derivatives $\mathbf{7}$ and $\mathbf{1 1}$ were transformed to the respective aniline ( 8 and 12 , respectively) by the following procedure. $\mathrm{Zn}$ in powder (100 mg, previously treated with $\mathrm{HCl} 5 \%)$ and ammonium formate $(1 \mathrm{~mL})$ were added to a stirred solution of nitroeugenols $\left(7,200 \mathrm{mg}, 9.6 \times 10^{-4} \mathrm{~mol} ; \mathbf{1 1}, 100 \mathrm{mg}, 4.48 \times 10^{-4} \mathrm{~mol}\right)$ in methanol (5.0-10 mL). The solution was stirred at room temperature for $5 \mathrm{~h}$, and complete disappearance of the starting product was confirmed by TLC (AcOEt:n-hexane, 1:3). The reacted mixture was filtered, and the solvent evaporated in vacuum. The crude reaction product was dissolved in $\mathrm{AcOEt}(10 \mathrm{~mL})$ and the organic phase was washed with brine $(3 \times 10 \mathrm{~mL})$, dried with anhydrous $\mathrm{Na}_{2} \mathrm{SO}_{4}$ and vacuum evaporated. The pure product was obtained by CC.

Acetylation reaction. Phenols 7, 8 and aniline 12 were reacted with acetic anhydride to give 10,9 , and 13, respectively, by the following synthetic procedure. To a stirred solution of phenol $\left(100 \mathrm{mg}, 5.6 \times 10^{-4} \mathrm{~mol}\right)$ or aniline $\left(100 \mathrm{mg}, 4.48 \times 10^{-4} \mathrm{~mol}\right)$ in dichloromethane $(15 \mathrm{~mL})$ was added $4-\mathrm{N}, \mathrm{N}$-dimethylaminopyridine (DMAP) $\left(10 \mathrm{mg}, 8.2 \times 10^{-5} \mathrm{~mol}\right)$. Acetic anhydride $(0.25 \mathrm{~mL})$ was added and the reaction was left to continue at room temperature (1.5-2 $\mathrm{h}$ for phenols; $1.5 \mathrm{~h}$ for aniline). After this period, complete disappearance of the starting product was confirmed by means of the TLC (ethyl acetate: n-hexane 1:3). Aqueous potassium hydrogen sulphate solution $(10 \%, 20 \mathrm{~mL}$ ) was added, and the organic phase was extracted with dichloromethane. The extract was washed with water $(3 \times 20 \mathrm{~mL})$, dried with anhydrous $\mathrm{Na}_{2} \mathrm{SO}_{4}$ and vacuum evaporated. Pure compounds were obtained by CC. 
4-allyl-2-amino-6-methoxyphenol (8): Compound 8 was synthesized from the nitroeugenol derivative 7 by reduction of the nitro group. Pure compound 8 was obtained by CC (1:8-1:7, AcOEt in hexane), as white crystal $\left(94.5 \mathrm{mg}, 55 \%\right.$ yield); melting point: $107-108^{\circ} \mathrm{C}$. IR (film) $v_{\max } / \mathrm{cm}^{-1}$ : $3308(\mathrm{OH}), 3372(\mathrm{NH}), 3308\left(\mathrm{C}=\mathrm{CH}\right.$ Ar), $3072\left(\mathrm{CH}=\mathrm{CH}_{2}\right), 1608(\mathrm{C}=\mathrm{C}), 1221(\mathrm{C}-\mathrm{N}), 1190(\mathrm{C}-\mathrm{O}), 1132$ (C-O), 1080, 896. ${ }^{1} \mathrm{H}$ NMR: $\delta 3.24\left(2 \mathrm{H}, \mathrm{d}, J=6.7 \mathrm{~Hz}, \mathrm{H}-1^{\prime}\right) ; 3.69\left(2 \mathrm{H}, \mathrm{b} . \mathrm{s}, \mathrm{NH}_{2}\right) ; 3.84\left(3 \mathrm{H}, \mathrm{s}, \mathrm{OCH}_{3}\right)$; $5.05\left(2 \mathrm{H}, \mathrm{m}, \mathrm{H}-3^{\prime}\right) ; 5.33(1 \mathrm{H}, \mathrm{s}, \mathrm{OH}) ; 5.93\left(1 \mathrm{H}, \mathrm{m}, \mathrm{H}-2^{\prime}\right) ; 6.19(1 \mathrm{H}, \mathrm{s}, \mathrm{H}-3) ; 6.25$ (1H, s, H-5). ${ }^{13} \mathrm{C}$ NMR: $\delta$ 40.1(C-1'); $55.9\left(\mathrm{OCH}_{3}\right) ; 101.8$ (C-5); 109.4 (C-3'); 115.3 (C-3); 131.1 (C-4); 131.6 (C-6); 138.0 (C-1); 134.0 (C-2'); 137.9 (C-1); 146.6 (C-2).

2-acetamide-4-allyl-6-methoxyphenyl acetate (9): Compound 9 was synthesized by acetylation of 8. Pure compound 9 was obtained by CC (1:9-1:5, ethyl acetate in hexane) as white crystal (103 mg, $70 \%$ ); melting point: $146-149^{\circ} \mathrm{C}$; IR (film) vmax $/ \mathrm{cm}^{-1}$ : $3320(\mathrm{~N}-\mathrm{H}), 3060-2800(\mathrm{C}=\mathrm{C} \mathrm{Ar}), 1750(\mathrm{C}=\mathrm{O})$, 1250 (C-CO-O), 1120 (C-O), 900-730 (C-H Ar). ${ }^{1} \mathrm{H}$ NMR: $\delta 2.15$ (3H, s, C-CH 3 ); 2.35 (3H, s, C-CH 3 ); 3.36 $\left(2 \mathrm{H}, \mathrm{d}, J=6.5, \mathrm{H}-1^{\prime}\right) ; 3.80\left(3 \mathrm{H}, \mathrm{s}, \mathrm{OCH}_{3}\right) ; 5.10\left(2 \mathrm{H}, \mathrm{m}, \mathrm{H}-3^{\prime}\right) ; 5.95\left(1 \mathrm{H}, \mathrm{m}, \mathrm{H}-2^{\prime}\right) ; 6.56(1 \mathrm{H}, \mathrm{s}, \mathrm{H}-3) ; 7.14$ (1H, b.s, -NH); $7.70(1 \mathrm{H}, \mathrm{s}, \mathrm{H}-5) .{ }^{13} \mathrm{C}$ NMR: $\delta 20.5\left(\mathrm{CH}_{3} \mathrm{CO}_{2}\right) ; 24.7\left(\mathrm{CH}_{3} \mathrm{CO}_{2}\right) ; 40.4\left(\mathrm{C}-1^{\prime}\right) ; 56.0\left(\mathrm{OCH}_{3}\right)$; 108.0 (C-5); 113.9 (C-3'); 116.3 (C-3); 127.9 (C-4); 130.9 (C-6); 136.8 (C-2'); 138.9 (C-1); 150.7 (C-2); 168.0 $\left(\mathrm{CH}_{3} \mathrm{CO}_{2}\right) ; 168.4\left(\mathrm{CH}_{3} \mathrm{CO}_{2}\right)$.

4-allyl-2-methoxy-6-nitrophenyl acetate (10): Compound 10 was synthesized by acetylation of 7. Pure compound 10 was obtained by CC (1:9-1:7, ethyl acetate in hexane) as yellow crystal ( $0.45 \mathrm{~g}$, $75 \%)$; melting point: $60-61^{\circ} \mathrm{C}$; IR (film) $v$ max $/ \mathrm{cm}^{-1}$ : 3100-2800 (C=C Ar), $1750(\mathrm{C}=\mathrm{O}), 1550\left(-\mathrm{NO}_{2}\right)$, 1250 (C-CO-O), 1250-1050 (C-O), 900-730 (C-H Ar). ${ }^{1} \mathrm{H}$ NMR: $\delta 2.36\left(3 \mathrm{H}, \mathrm{s}, \mathrm{CO}-\mathrm{CH}_{3}\right) ; 3.43(2 \mathrm{H}, \mathrm{d}$, $\left.J=6.5 \mathrm{~Hz} . \mathrm{H}-1^{\prime}\right) ; 3.87\left(3 \mathrm{H}, \mathrm{s},-\mathrm{O}-\mathrm{CH}_{3}\right) ; 5.17\left(2 \mathrm{H}, \mathrm{m}, \mathrm{H}-3^{\prime}\right) ; 5.92\left(1 \mathrm{H}, \mathrm{m}, \mathrm{H}-2^{\prime}\right) ; 7.03(1 \mathrm{H}, \mathrm{s}, \mathrm{H}-3) ; 7.43(1 \mathrm{H}$, s, H-5). ${ }^{13} \mathrm{C}$ NMR: $\delta 20.2\left(\mathrm{CH}_{3} \mathrm{CO}_{2}\right) ; 39.5\left(\mathrm{C}-1^{\prime}\right) ; 56.5\left(\mathrm{OCH}_{3}\right) ; 116.0(\mathrm{C}-5) ; 117.1\left(\mathrm{C}-3^{\prime}\right) ; 117.4(\mathrm{C}-3) ; 132.1$ (C-4); 135.2 (C-6); 139.1 (C-2'); 142.4 (C-1); 152.6 (C-2); $167.9\left(\mathrm{CH}_{3} \mathrm{CO}_{2}\right)$.

5-allyl-1,2-dimethoxy-3-nitrobenzene (11): Potassium carbonate $\left(1.0 \mathrm{~g}, 7.25 \times 10^{-3} \mathrm{~mol}\right)$ was added to a stirred solution of $7\left(600 \mathrm{mg}, 2.87 \times 10^{-3} \mathrm{~mol}\right)$ in dry acetone $(60 \mathrm{~mL})$. Then, dimethyl sulphate $\left(1.2 \mathrm{~mL}, 1.27 \times 10^{-2} \mathrm{~mol}\right)$ was added and the reaction was left to continue over night under reflux. Complete disappearance of the starting product was confirmed by TLC (1:3 ethyl acetate: hexane). The crude reaction product is diluted in acetone $(30 \mathrm{~mL})$, water $(50 \mathrm{~mL})$, and extracted with dichloromethane $(3 \times 50 \mathrm{~mL})$. The extract is dried with anhydrous $\mathrm{Na}_{2} \mathrm{SO}_{4}$ and vacuum evaporated. Pure product $(513 \mathrm{mg}, 80 \%)$ was obtained by CC (1:9-1:7, ethyl acetate in hexane as marron oil. Compound 11: IR (film) $v$ max $/ \mathrm{cm}^{-1}: 3100-2800\left(\mathrm{C}=\mathrm{C}\right.$ Ar), $1550\left(-\mathrm{NO}_{2}\right), 1400-1000(\mathrm{C}-\mathrm{O}), 1000-650$ $\left(\mathrm{H}_{2} \mathrm{C}=\mathrm{CH}_{2}\right) .{ }^{1} \mathrm{H}$ RMN: $\delta 3.38\left(2 \mathrm{H}, \mathrm{d}, J=6.4 \mathrm{~Hz}, \mathrm{H}-1^{\prime}\right) ; 3.90\left(3 \mathrm{H}, \mathrm{s}, \mathrm{OCH}_{3}\right) ; 3.95\left(3 \mathrm{H}, \mathrm{s}, \mathrm{OCH}_{3}\right) ; 5.14(2 \mathrm{H}$, $\left.\mathrm{m}, \mathrm{H}-3^{\prime}\right) ; 5.91\left(1 \mathrm{H}, \mathrm{m}, \mathrm{H}-2^{\prime}\right) ; 6.92(1 \mathrm{H}, \mathrm{s}, \mathrm{H}-3) ; 7.16(1 \mathrm{H}, \mathrm{s}, \mathrm{H}-5) .{ }^{13} \mathrm{C} \mathrm{RMN}$ : $\delta 39.6\left(\mathrm{C}-1^{\prime}\right) ; 56.4\left(\mathrm{OCH}_{3}\right)$; $61.9\left(\mathrm{OCH}_{3}\right) ; 115.6(\mathrm{C}-6) ; 116.3\left(\mathrm{C}-3^{\prime}\right) ; 117.3$ (C-3); 135.7 (C-4); $136.3\left(\mathrm{C}-2^{\prime}\right) ; 141.1$ (C-5); 144.7 (C-1); $153.9(\mathrm{C}-2)$.

5-allyl-2,3-dimethoxyaniline (12): Aniline $\mathbf{1 2}$ was synthesized from the nitroeugenol derivative $\mathbf{1 1}$ by reduction of the nitro group. Pure compound 12 was obtained by CC (1:8-1:5, AcOEt in hexane) as marron oil (45.7 mg, 46\% yield). Compound 12: IR (film) $v_{\max } / \mathrm{cm}^{-1}: 3500-3300\left(\mathrm{NH}_{2}\right), 3100-2800$ $\left(\mathrm{C}=\mathrm{C}\right.$ Ar), $1400-1000(\mathrm{C}-\mathrm{O}), 1000-650\left(\mathrm{H}_{2} \mathrm{C}=\mathrm{CH}_{2}\right) .{ }^{1} \mathrm{H}$ NMR: $\left.\delta 3.25(2 \mathrm{H}, \mathrm{d}, J=6.4 \mathrm{~Hz}, \mathrm{H1})^{\prime}\right) ; 3.69(2 \mathrm{H}, \mathrm{b} . \mathrm{s}$, $\left.\mathrm{NH}_{2}\right) ; 3.79\left(3 \mathrm{H}, \mathrm{s}, \mathrm{OCH}_{3}\right) ; 3.82\left(3 \mathrm{H}, \mathrm{s}, \mathrm{OCH}_{3}\right) ; 5.07\left(2 \mathrm{H}, \mathrm{m}, \mathrm{H}-3^{\prime}\right) ; 5.95\left(1 \mathrm{H}, \mathrm{m}, \mathrm{H}-2^{\prime}\right) ; 6.17(1 \mathrm{H}, \mathrm{s}, \mathrm{H}-3)$; $6.23(1 \mathrm{H}, \mathrm{s}, \mathrm{H}-5) .{ }^{13} \mathrm{C} \delta \mathrm{NMR}: 40.3\left(\mathrm{C}-1^{\prime}\right) ; 55.6\left(\mathrm{OCH}_{3}\right) ; 59.9\left(\mathrm{OCH}_{3}\right) ; 102.7(\mathrm{C}-6) ; 108.8\left(\mathrm{C}-3^{\prime}\right) ; 115.7$ (C-3); 134.3 (C-4); 136.2 (C-2'); 137.5 (C-5); 140.2 (C-1); 152.8 (C-2).

$\mathrm{N}$-(5-allyl-2,3-dimethoxyphenyl) acetamide (13): Compound 13 was synthesized by acetylation of 12. Pure compound 13 was obtained by CC (1:5-1:3, ethyl acetate in hexane) as white crystal (64 mg, 53\%); melting point: $78-79^{\circ} \mathrm{C}$; IR (film) $v_{\max } / \mathrm{cm}^{-1}: 3300(\mathrm{~N}-\mathrm{H}), 3100-2800$ (C=C Ar), 1715 (R-(CO)-R'), 1400-1000 (C-O), 1000-650 ( $\left.\mathrm{H}_{2} \mathrm{C}=\mathrm{CH}_{2}\right) .{ }^{1} \mathrm{H}$ NMR: $\delta 2.18\left(3 \mathrm{H}, \mathrm{s}, \mathrm{CH}_{3} \mathrm{CON}\right) ; 3.31\left(2 \mathrm{H}, \mathrm{d}, J=6.4 \mathrm{~Hz}, \mathrm{H}-1^{\prime}\right)$; $3.82\left(3 \mathrm{H}, \mathrm{s}, \mathrm{OCH}_{3}\right) ; 3.82\left(3 \mathrm{H}, \mathrm{s}, \mathrm{OCH}_{3}\right) ; 5.07\left(2 \mathrm{H}, \mathrm{m}, \mathrm{H}-3^{\prime}\right) ; 5.92\left(1 \mathrm{H}, \mathrm{m}, \mathrm{H}-2^{\prime}\right) ; 6.47(1 \mathrm{H}, \mathrm{s}, \mathrm{H}-3) ; 7.81$ (1H, s, H-5); $7.83(-\mathrm{HN}) .{ }^{13} \mathrm{C}$ NMR: $\delta 24.7\left(\mathrm{CH}_{3} \mathrm{CON}\right) ; 40.3\left(\mathrm{C}-1^{\prime}\right) ; 55.6\left(\mathrm{OCH}_{3}\right) ; 60.5\left(\mathrm{OCH}_{3}\right) ; 107.6(\mathrm{C}-6)$; 112.4 (C-3'); 115.7 (C-3); 131.7 (C-4); 135.4 (C-2'); 136.2 (C-5); 137.1 (C-1); 151.7 (C-2); $168.2\left(\mathrm{CH}_{3} \mathrm{CON}\right)$. 


\subsection{Biological Assays}

\subsubsection{B. cinerea Isolates}

PN2 is a native resistant isolate of $B$. cinerea obtained from cherry. It was maintained and grown under conditions previously described [33]. Its sensibility to current fungicides was tested following a described method [34]. Briefly, to test the single fungicide resistance spectra, of collected Botrytis isolates, discriminatory fungicide concentrations of the following fungicides were used: carbendazim $5 \mu \mathrm{g} / \mathrm{mL}$; cyprodinil $5 \mu \mathrm{g} / \mathrm{mL}$; fenhexamid $5 \mu \mathrm{g} / \mathrm{mL}$; iprodion $5 \mu \mathrm{g} / \mathrm{mL}$; tebuconazole $7 \mu \mathrm{g} / \mathrm{mL}$; pyrimethanil $10 \mu \mathrm{g} / \mathrm{mL}$; boscalid $5 \mu \mathrm{g} / \mathrm{mL}$ and tolnaftate $5 \mu \mathrm{g} / \mathrm{mL}$. These concentrations were chosen according to $\mathrm{IC}_{50}$ values of single fungicide resistant strains [35]. In addition, the virulence of PN2 was evaluated by evaluating the damage produced by Botrytis isolate on a tomato. Tomatoes fruit were inoculated with $10 \mu \mathrm{L}$ of conidia suspension $\left(2.5 \times 10^{6}\right.$ conidia $\left./ \mathrm{mL}\right)$ and incubated at $22{ }^{\circ} \mathrm{C}$. The photographical recording was made after 1-4 days post-inoculation to evaluate fruit damage. The Gamborg medium and 7AC isolate (gently provided by Diagnofruit S.A. Santiago, Chile) were used as negative and positive controls, respectively.

\subsubsection{Effect of Eugenol Derivatives on Mycelial Growth of B. cinerea in Solid Media}

Fungitoxicity of eugenol and synthetic derivatives, and of commercial fungicide BC-1000, was assessed using the radial growth test on malt-yeast extract agar [36]. All the compounds, except BC-1000, were applied in dichloromethane solution at different final concentrations (20, 40, 80, 160 ppm). Eugenol and its synthetic derivatives were completely soluble at all tested concentrations. An aliquot of these solutions $(200 \mu \mathrm{L})$ was added to $7 \mathrm{~mL}$ of malt-yeast extract agar. The amount of added dichloromethane was identical in controls and treatment assays. The medium with presence or absence of synthetized compounds as well as BC-1000 was poured into $6 \mathrm{~cm}$ diameter Petri dishes. Dishes were left open in a biosecurity hood for $40 \mathrm{~min}$ to remove solvent. After solvent evaporation, Petri dishes were inoculated with $5 \mathrm{~mm}$ diameter agar discs with thin mycelium of $B$. cinerea. Cultures were incubated in the dark at $22{ }^{\circ} \mathrm{C}$ during several days. Mycelial growth diameters were measured daily, and inhibition percentages were calculated using the following equation

$$
\text { Growth inhibition }(\%)=\frac{\left(d_{C}-d_{0}\right)-\left(d_{S}-d_{0}\right)}{\left(d_{C}-d_{0}\right)} \times 100
$$

where $d_{C}, d_{0}$ and $d_{S}$ represent diameters (in $\mathrm{mm}$ ) of blank control fungus, fungus agar disc, and compound-treated fungus. Inhibition percentages were plotted as a function of fungicide concentration using a dose-response equation, for all tested compounds. The $\mathrm{IC}_{50}$ values were obtained by fitting of data to this curve. Plotting of the data, fitting, and $\mathrm{IC}_{50}$ calculation were carried out with Origin v8.0 (OriginLab, Northhampton, MA, USA). Significant differences were evaluated with a two-way analysis of variance (Tukey's test; $p<0.05$ ).

\subsubsection{Effect of Eugenol and its Derivatives on ROS Production by Botrytis cinerea}

The production of reactive oxygen species was measured following a described procedure [36,37]. Menadione was used as a positive control. This molecule has been described as an inducer of ROS generation, since it is capable of both redox cycling and arylating nucleophilic substrates by Michael addition [37,38]. The ROS was evaluated using ROS-GLOtm $\mathrm{H}_{2} \mathrm{O}_{2}$ assay kit (Promega, Madison, WI, USA) [37]. Briefly, conidia $(79 \mu \mathrm{L})$ were plated in a 96-well plate at a concentration of $1 \times 10^{5}$ conidiam $\mathrm{L}^{-1}$ /well. Later, each well was incubated in presence of each compound at their $\mathrm{IC}_{50}$ concentration, $20 \mu \mathrm{L}$ of buffer substrate $\mathrm{H}_{2} \mathrm{O}_{2}$ and cultured for $2 \mathrm{~h}$ at $21 \pm 1^{\circ} \mathrm{C}$. After this period of incubation, $100 \mu \mathrm{L}$ of ROS-GLOtm reagent was added to each well and incubated for $20 \mathrm{~min}$ at room temperature. The ROS production was measured using a luminometer (Tecan infinite m200pro; Tecan 
Group Ltd., Hombrechtikon, Switzerland). Mean values with at least significant difference $(p<0.05)$ were considered.

\section{Conclusions}

A series of eugenol derivatives has been synthesized and their antifungal activity on mycelial growth of $B$. cinerea has been evaluated. The growth inhibition activity depends on the chemical structure of eugenol derivatives. An analysis of the structure-activity relationship suggests that these compounds act on fungus by two mechanisms, i.e., accumulation on the fungus membrane and chemical reactions with unsaturated chains or enzymatic-mediated reduction. The first is controlled by the lipophilic character of these molecules and the second is due to the presence of strong electron withdrawing groups in the aromatic ring. This action leads to the disruption of fungus membranes and ROS production. Our results show that some eugenol derivatives have a much higher antifungal activity or, at least, comparable to the commercial fungicide BC-1000. Finally, the high activity values presented by the nitro compounds make them potential antifungal agents for the chemical control of B. cinerea.

Author Contributions: A.B., C.S., M.T., H.C. and R.M. collaborated in the synthesis and purification of 2-allylphenolderivatives; H.C. and A.F.O. collaborated in the discussion of structure-activity relationship, and writing of the manuscript; E.Z. and D.C. performed the bioassays; E.S.-M. supervised the biological work and wrote the biological component of this manuscript; H.C. and A.F.O. collaborated in the discussion and interpretation of the results, manuscript redaction, and corrections.

Funding: This research was funded by FONDECYT grant number 1170706 and 1130742.

Acknowledgments: The authors are grateful to FONDECYT for financial support of this work under Grant 1170706 and 1130742.

Conflicts of Interest: The authors declare no conflict of interest.

\section{References}

1. Romanazzi, G.; Droby, S. Control Strategies for Postharvest Grey Mould on Fruit Crops. In Botrytis-The Fungus, the Pathogen and Its Management in Agricultural Systems; Fillinger, S., Elad, Y., Eds.; Springer: Berlin/Heidelberg, Germany, 2016; pp. 217-228.

2. Fillinger, S.; Elad, Y. Chemical Control and Resistance Management of Botrytis Diseases; Springer International Publishing: Cham, Switzerland, 2016.

3. Esterio, M.; Munoz, G.; Ramos, C.; Cofre, G.; Estevez, R.; Salinas, A.; Auger, J. Characterization of Botrytis cinerea Isolates Present in Thompson Seedless Table Grapes in the Central Valley of Chile. Plant Dis. 2011, 95, 683-690. [CrossRef] [PubMed]

4. Grayer, R.J.; Harborne, J.B. A Survey of Antifungal Compounds from Higher-Plants, 1982-1993. Phytochemistry 1994, 37, 19-42. [CrossRef]

5. Grayer, R.J.; Kokubun, T. Plant-fungal interactions: The search for phytoalexins and other antifungal compounds from higher plants. Phytochemistry 2001, 56, 253-263. [CrossRef]

6. Caruso, F.; Mendoza, L.; Castro, P.; Cotoras, M.; Aguirre, M.; Matsuhiro, B.; Isaacs, M.; Rossi, M.; Viglianti, A.; Antonioletti, R. Antifungal Activity of Resveratrol against Botrytis cinerea Is Improved Using 2-Furyl Derivatives. PLoS ONE 2011, 6, e25421. [CrossRef]

7. Saiz-Urra, L.; Racero, J.C.; Macias-Sanchez, A.J.; Hernandez-Galan, R.; Hanson, J.R.; Perez-Gonzalez, M.; Collado, I.G. Synthesis and Quantitative Structure-Antifungal Activity Relationships of Clovane Derivatives against Botrytis cinerea. J. Agric. Food Chem. 2009, 57, 2420-2428. [CrossRef]

8. Chung, G.; Im, S.T.; Kim, Y.H.; Jung, S.J.; Rhyu, M.R.; Oh, S.B. Activation of transient receptor potential ankyrin 1 by eugenol. Neuroscience 2014, 261, 153-160. [CrossRef]

9. Daniel, A.N.; Sartoretto, S.M.; Schmidt, G.; Caparroz-Assef, S.M.; Bersani-Amado, C.A.; Cuman, R.K.N. Anti-inflammatory and antinociceptive activities of eugenol essential oil in experimental animal models. Braz. J. Pharmacogn. 2009, 19, 212-217. [CrossRef] 
10. Ali, S.M.; Khan, A.A.; Ahmed, I.; Musaddiq, M.; Ahmed, K.S.; Polasa, H.; Rao, L.V.; Habibullah, C.M.; Sechi, L.A.; Ahmed, N. Antimicrobial activities of Eugenol and Cinnamaldehyde against the human gastric pathogen Helicobacter pylori. Ann. Clin. Microbiol. Antimicrob. 2005, 4, 20. [CrossRef]

11. Saeed, S.; Tariq, P. In vitro antibacterial activity of clove against gram negative bacteria. Pak. J. Bot. 2008, 40, 2157-2160.

12. Park, M.J.; Gwak, K.S.; Yang, I.; Choi, W.S.; Jo, H.J.; Chang, J.W.; Jeung, E.B.; Choi, I.G. Antifungal activities of the essential oils in Syzygium aromaticum (L.) Merr. Et Perry and Leptospermum petersonii bailey and their constituents against various dermatophytes. J. Microbiol. 2007, 45, 460-465. [PubMed]

13. Pinto, E.; Vale-Silva, L.; Cavaleiro, C.; Salgueiro, L. Antifungal activity of the clove essential oil from Syzygium aromaticum on Candida, Aspergillus and dermatophyte species. J. Med. Microbiol. 2009, 58, 1454-1462. [CrossRef] [PubMed]

14. Ogata, M.; Hoshi, M.; Urano, S.; Endo, T. Antioxidant activity of eugenol and related monomeric and dimeric compounds. Chem. Pharm. Bull. 2000, 48, 1467-1469. [CrossRef]

15. Yang, Y.C.; Lee, S.H.; Lee, W.J.; Choi, D.H.; Ahn, Y.J. Ovicidal and adulticidal effects of Eugenia caryophyllata bud and leaf oil compounds on Pediculus capitis. J. Agric. Food Chem. 2003, 51, 4884-4888. [CrossRef] [PubMed]

16. Zheng, G.Q.; Kenney, P.M.; Lam, L.K.T. Sesquiterpenes from clove (eugenia caryophyllata) as potential anticarcinogenic agents. J. Nat. Prod. 1992, 55, 999-1003. [CrossRef] [PubMed]

17. Pramod, K.; Ansari, S.H.; Ali, J. Eugenol: A natural compound with versatile pharmacological actions. Nat. Prod. Commun. 2010, 5, 1999-2006. [CrossRef]

18. Chaieb, K.; Hajlaoui, H.; Zmantar, T.; Kahla-Nakbi, A.B.; Rouabhia, M.; Mahdouani, K.; Bakhrouf, A. The chemical composition and biological activity of clove essential oil, Eugenia caryophyllata (Syzigium aromaticum L. Myrtaceae): A short review. Phytother. Res. 2007, 21, 501-506. [CrossRef] [PubMed]

19. Zemek, J.; Košíková, B.; Augustin, J.; Joniak, D. Antibiotic properties of lignin components. Folia Microbiol. 1979, 24, 483-486. [CrossRef]

20. Himejima, M.; Kubo, I. Antimicrobial agents from licaria puchuri-major and their synergistic effect with polygodial. J. Nat. Prod. 1992, 55, 620-625. [CrossRef] [PubMed]

21. Kubo, I.; Muroi, H.; Himejima, M. Combination effects of antifungal nagilactones against candida albicans and two other fungi with phenylpropanoids. J. Nat. Prod. 1993, 56, 220-226. [CrossRef]

22. Fujita, K.I.; Kubo, I. Potentiation of fungicidal activities of trans-anethole against saccharomyces cerevisiae under hypoxic conditions. J. Biosci. Bioeng. 2004, 98, 490-492. [CrossRef]

23. De Jesus Faria, T.; Ferreira, R.S.; Yassumoto, L.; De Souza, J.R.P.; Ishikawa, N.K.; De Melo Barbosa, A. Antifungal activity of essential oil isolated from Ocimum gratissimum L. (eugenol chemotype) against phytopathogenic fungi. Braz. Arch. Biol. Technol. 2006, 49, 867-871. [CrossRef]

24. Campaniello, D.; Corbo, M.R.; Sinigaglia, M. Antifungal Activity of Eugenol against Penicillium, Aspergillus, and Fusarium Species. J. Food Prot. 2010, 73, 1124-1128. [CrossRef]

25. Carrasco, H.; Raimondi, M.; Svetaz, L.; Di Liberto, M.; Rodriguez, M.V.; Espinoza, L.; Madrid, A.; Zacchino, S. Antifungal activity of eugenol analogues. Influence of different substituents and studies on mechanism of action. Molecules 2012, 17, 1002-1024. [CrossRef]

26. Amiri, A.; Dugas, R.; Pichot, A.L.; Bompeix, G. In vitro and in vitro activity of eugenol oil (Eugenia caryophylata) against four important postharvest apple pathogens. Int. J. Food Microbiol. 2008, 126, 13-19. [CrossRef] [PubMed]

27. Wang, C.; Zhang, J.; Chen, H.; Fan, Y.; Shi, Z. Antifungal activity of eugenol against Botrytis cinerea. Trop. Plant Pathol. 2010, 35, 137-143. [CrossRef]

28. Pal, C.; Bandyopadhyay, U. Redox-Active Antiparasitic Drugs. Antioxid. Redox Signal. 2012, 17, 555-582. [CrossRef] [PubMed]

29. Siegmund, U.; Viefhues, A. Reactive Oxygen Species in the Botrytis-Host Interaction. In Botrytis-The Fungus, the Pathogen and its Management in Agricultural Systems; Fillinger, S., Elad, Y., Eds.; Springer: Berlin/Heidelberg, Germany, 2016; pp. 268-289.

30. Martindale, J.L.; Holbrook, N.J. Cellular response to oxidative stress: Signaling for suicide and survival. J. Cell. Physiol. 2002, 192, 1-15. [CrossRef] 
31. Gill, A.O.; Holley, R.A. Mechanisms of bactericidal action of cinnamaldehyde against Listeria monocytogenes and of eugenol against L. monocytogenes and Lactobacillus sakei. Appl. Environ. Microbiol. 2004, 70, 5750-5755. [CrossRef] [PubMed]

32. Ntamila, M.S.; Hassanali, A. Isolation of oil of clove and separation of eugenol and acetyl eugenol: An instructive experiment for beginning chemistry undergraduates. J. Chem. Ed. 1976, 53, 263. [CrossRef]

33. Carrasco, H.; Robles-Kelly, C.; Rubio, J.; Olea, A.F.; Martínez, R.; Silva-Moreno, E. Antifungal effect of polygodial on Botrytis cinerea, a fungal pathogen affecting table grapes. Int. J. Mol. Sci. 2017, 18, 2251. [CrossRef]

34. Leroch, M.; Kretschmer, M.; Hahn, M. Fungicide resistance phenotypes of botrytis cinerea isolates from commercial vineyards in South West Germany. J. Phytopathol. 2011, 159, 63-65. [CrossRef]

35. Leroux, P.; Chapeland, F.; Desbrosses, D.; Gredt, M. Patterns of cross-resistance to fungicides in Botryotinia fuckeliana (Botrytis cinerea) isolates from French vineyards. Crop Prot. 1999, 18, 687-697. [CrossRef]

36. Robles-Kelly, C.; Rubio, J.; Thomas, M.; Sedan, C.; Martinez, R.; Olea, A.F.; Carrasco, H.; Taborga, L.; Silva-Moreno, E. Effect of drimenol and synthetic derivatives on growth and germination of Botrytis cinerea: Evaluation of possible mechanism of action. Pestic. Biochem. Physiol. 2017, 141, 50-56. [CrossRef] [PubMed]

37. Kelts, J.L.; Cali, J.J.; Duellman, S.J.; Shultz, J. Altered cytotoxicity of ROS-inducing compounds by sodium pyruvate in cell culture medium depends on the location of ROS generation. Springerplus 2015, 4, 269. [CrossRef] [PubMed]

38. Scott, G.K.; Atsriku, C.; Kaminker, P.; Held, J.; Gibson, B.; Baldwin, M.A.; Benz, C.C. Vitamin K3 (menadione)-induced oncosis associated with keratin 8 phosphorylation and histone $\mathrm{H} 3$ arylation. Mol. Pharmacol. 2005, 68, 606-615. [CrossRef] [PubMed]

Sample Availability: Samples of the compounds 8-13 are available from the authors.

(C) 2019 by the authors. Licensee MDPI, Basel, Switzerland. This article is an open access article distributed under the terms and conditions of the Creative Commons Attribution (CC BY) license (http://creativecommons.org/licenses/by/4.0/). 